\title{
PENGEMBANGAN PERANGKAT PEMBELAJARAN MODEL PROBLEM BASED LEARNING (PBL) UNTUK MENINGKATKAN KETERAMPILAN BERPIKIR KRITIS MAHASISWA PGMI UNIPDU JOMBANG
}

\author{
Miftakhul IImi S. Putra \\ Andik Wahyun Muqoyyidin \\ Fakultas Agama Islam Universitas Pesantren Tinggi Darul Ulum Jombang \\ Email :mifta.unipdu@gmail.com
}

\begin{abstract}
Abstrak
Penelitian ini bertujuan untuk mendeskripsikan efektivitas pembelajaran berorientasi Model PBL ditinjau dari beberapa aspek sebagai berikut: 1)Aktivitas mahasiswa selama mengikuti pembelajaran PPKn yang berorientasi Model PBL; 2) Respon mahasiswa terhadap kegiatan pembelajaran PPKn berorientasi Model PBL. Pada penelitian ini, subjek diambil dari mahasiswa Semester 6 PGMI Unipdu Jombang. Pengumpulan data dilakukan dengan cara tes dan wawancara. Selanjutnya untuk menguji kredibilitas data, dilakukan triangulasi waktu. Pada waktu yang berbeda diberikan tes dan wawancara dengan masalah yang ekuivalen dengan tes sebelumnya. Oleh karena itu, penulis melakukan penelitian untuk mengetahui hasil belajar mahasiswa dalam menggunakan Model PBL. Penelitian ini dengan menggunakan "one group pretest-posttest design". Data dikumpulkan dengan menggunakan tes, dan dianalisis dengan analisis statistik deskriptif. Hasil penelitian disajikan dalam bentuk tabel dan diagram. Hasil penelitian menyatakan bahwa Ujicoba pembelajaran efektif menunjang kegiatan belajar mengajar yang didasarkan pada rata-rata pengelolaan pembelajaran berkategori baik. keseluruhan sintaks Model Pembelajaran $P B L$ terlaksana $100 \%$. Aktivitas mahasiswa selama kegiatan belajar mengajar menunjukkan bahwa mahasiswa belajar aktif. Respon mahasiswa terhadap Model Pembelajaran PBL adalah kategori baik dan positif.
\end{abstract}

Kata Kunci : Model PBL, Pembelajaran PPKn, Keterampilan Berpikir Kritis

\section{PENDAHULUAN}

Mata kuliah PPKn di mata mahasiswa PGMI UNIPDU Jombang adalah salah satu mata pelajaran yang tidak menarik. Dosen harus berusaha menentukan pendekatan, model dan metode yang tepat agar materi yang disajikan dapat dimengerti dan dipahami serta para mahasiswa tahu kegunaan materi tersebut dalam 
kehidupan sehari-hari. Sehingga tercipta suasana pembelajaran ${ }^{1}$ yang menyenangkan, aktif, dan efektif.

Keterampilan berpikir kritis termasuk salah satu keterampilan berpikir tingkat tinggi. Keterampilan berpikir kritis secara esensial merupakan keterampilan menyelesaikan masalah (problem solving). Keterampilan berpikir kritis adalah kemampuan bernalar dan berpikir reflektif yang diarahkan untuk memutuskan hal-hal yang meyakinkan untuk dilakukan. ${ }^{2}$ Keterampilan berpikir kritis perlu dikembangkan dalam diri mahasiswa karena melalui keterampilan berpikir kritis mahasiswa dapat lebih mudah memahami konsep, peka akan masalah yang terjadi sehingga dapat memahami dan menyelesaikan masalah dan mampu mengaplikasikan konsep-konsep dalam situasi yang berbeda. Keterampilan berpikir kritis ini sangat penting bagi calon guru MI dikarenakan keterampilan berpikir kritis lebih banyak diterapkan saat menjadi guru MI dalam proses pembelajaran di kelas.

PGMI UNIPDU Jombang adalah program studi yang baru dalam Fakultas Agama Islam Unipdu Jombang, banyak tantangan dan kendala yang dihadapi untuk meningkatkan mutu akademik. Apalagi input mahasiswa yang masuk ke PGMI UNIPDU Jombang adalah mahasiswa yang memiliki latar belakang yang heterogen baik dari latar belakang ekonomi maupun latar belakang kompetensi dasar yang dimilikinya.

Hasil penelitian tentang pembelajaran model PBL sampai sekarang ini telah banyak dilakukan tetapi hanya terbatas dilakukan pada Sekolah Menengah. Hal ini disebabkan Model PBL ini masih sulit, Kesulitannya terletak pada proses melatihkan keterampilan berpikir tingkat tinggi ${ }^{3}$, dan keterampilan pemecahan masalah ${ }^{4}$, sehingga jarang sekali penelitian tentang pembelajaran PPKn dengan menggunakan model PBL dilakukan pada mahasiswa. Tetapi segala sesuatu dapat diberikan pada siapapun asal dengan cara yang benar. Begitu juga dengan pembelajaran PPKn dengan menggunakan model PBL dapat digunakan dalam kegiatan belajar mengajar pada mahasiswa asal digunakan dengan benar, disesuaikan dengan kebutuhan dan tingkat perkembangan mahasiswa di perguruan tinggi.

1 Rosa, O. F. (2015). Pengembangan modul pembelajaran IPA SMP pada materi tekanan berbasis keterampilan proses sains. Jurnal Pendidikan Fisika. Vol. 3 No. 1. 49-63.

2 Ennis, R. H. (1991). Critical thinking: A streamlined conception. Teaching Philosophy, 14(1), 524. Thinking. Alexandria: ASCD.

${ }^{3}$ Putra, MIS., Widodo, W, Jatmiko B. Mundilarto, M. (2018). The Development Of Science Cps (Collaborative Problem Solving) Learning Model To Improve Future Islamic Elementary School Teachers' Collaborative Problem-Solving Skills And Science Literacy. Unnes Science Education Journal 7 (1) 35-49

${ }^{4}$ Nur, M. 2000. Strategi - Strategi Belajar. Surabaya: Unipres 
Peneliti adalah Tim dosen FAI Unipdu, yang tertarik untuk melakukan penelitian pengembangan pembelajaran PPKn khususnya di kelas PGMI Semester 6 karena heterogenitas dari kelas tersebut dan tampak dari sikap para mahasiswa dalam belajar cukup beragam. Mahasiswa yang memiliki kemampuan tinggi merasa bosan ketika dosen memberikan penjelasan yang berulang-ulang, sedangkan mahasiswa yang berkemampuan rendah semakin terlihat jenuh.

Pembelajaran PPKn cukup sulit dilakukan untuk mahasiswa karena permasalahan yang ditekankan adalah permasalahan sehari-hari, dimana mahasiswa masih terbiasa dengan permasalahan akademik dan non akademik. Permasalahan sehari-hari adalah masalah yang ada di masyarakat, dan bukan merupakan masalah akademik seperti yang tercantum pada pembelajaran. Apabila permasalahan seharihari dapat hubungkan dengan konsep yang ada dalam pembelajaran, maka mahasiswa akan dapat menemukan sendiri konsep atau prinsip tersebut melalui pembelajaran PPKn dengan menggunakan model PBL.

Berdasarkan observasi awal yang dilakukan peneliti ditemukan beberapa permasalahan dalam pembelajaran PPKn di kelas PGMI, antara lain:

1. Aktivitas individu maupun kelompok belum terlihat maksimal, masih banyak mahasiswa yang lebih banyak diam dan kurang aktif.

2. Banyak tugas pekerjaaan rumah yang tidak dapat mereka selesaikan dengan berbagai macam alasan.

3. Diperlukan metode, dan model pembelajaran yang tepat untuk menumbuhkan minat dan aktivitas mahasiswa.

4. Hasil belajar pada UTS sebelumnya rendah, mahasiswa yang mampu mencapai hanya $52 \%$ keberhasilan.

Model PBL memiliki tujuan umum untuk meningkatkan keterampilan berpikir kritis serta keterampilan memecahkan masalah, perilaku dan keterampilan sosial sesuai peran orang dewasa, keterampilan untuk belajar secara mandiri ${ }^{5}$. Model PBL melibatkan peserta didik dalam menyelidiki sesuatu, membangkitkan minat bertanya serta memecahkan masalah-masalah yang nyata. ${ }^{6}$

5 Skinner, V. J., Braunack-Mayer, A. , \& Winning, T. A. (2015). The purpose and value for students of PBL groups for learning. Interdisciplinary Journal of Problem-based Learning, 9(1).

Ageorges, P., Bacila, A., Poutot, G., Blandin, B. (2014). Some lessons from a 3year experiment of problem based learning in physics in a French school of engineering. American Journal of Educational Research. Vol. 2 No. 8, pp. 564-567.

Klegeris, A., Bahniwal, M., Hurren, H. (2013) Improvement in generic problemsolving abilities of students by use of tutor-less problem-based learning in a large classroom setting. Life Sciences Education. Vol. 12, pp. 73-79.

6 Prahani, B. K., Nur, M., Yuanita, L. (2016). Validitas Model Self Confidence Collaborative Problem Solving. Seminar Nasional Unesa. Surabaya, 23 Januari 2016. 
Pada penelitian ini, peneliti memilih Model pembelajaran PBL dengan alasan, Model PBL pada pembelajaran PPKn ini sangat sesuai dipakai dengan materi-materi yang berkaitan dengan kehidupan sehari-hari. Sehingga mahasiswa tidak merasa jenuh dalam belajar PPKn, oleh karena itulah dosen harus mengambil tindakan yang dapat meningkatkan peran aktivitas mahasiswa untuk mendukung terlaksanakannya proses pembelajaran yang menarik dan bermakna. Oleh karena itu, penulis melakukan penelitian yang bertujuan untuk mendeskripsikan efektivitas pembelajaran berorientasi PBL ditinjau dari beberapa aspek yaitu: a) Aktivitas mahasiswa selama mengikuti pembelajaran yang berorientasi menggunakan PBL dan b) respon mahasiswa terhadap kegiatan pembelajaran berorientasi pembelajaran dengan menggunakan $P B L$ ?

Secara praktis, hasil penelitian ini memiliki manfaat untuk : a) Menjadi acuan bagi dosen/ pendidik dalam menerapkan pembelajaran yang menggunakan Model $P B L$ pada konsep lain yang relevan. b) Model PBL yang digunakan dalam penelitian ini dapat diimplementasikan di Kampus/Institust/Universitas lain yang kondisinya berbeda tetapi dengan penyesuaian-penyesuaian, sehingga dapat meningkatkan pemahaman berpikir kritis mahasiswa.

\section{METODE PENELITIAN}

Jenis penelitian yang dilakukan adalah penelitian eksperimental. Tujuan dari penelitian eksperimental ini untuk menyelidiki kemungkinan saling hubungan sebab akibat dengan cara mengenakan satu atau lebih kelompok eksperimental satu atau lebih kondisi perlakuan dan membandingkan hasilnya dengan satu atau lebih kelompok kontrol yang dikenai kondisi perlakuan. ${ }^{7}$ Subjek dalam penelitian adalah Dalam penelitian ini sumber data primernya adalah peserta didik PGMI Semester 6 Unipdu Jombang yang memprogram Mata Kuliah PPKN.

Penelitian ini menggunakan rancangan "one group pretest-posttest design"8, di mana digunakan satu kelompok subyek. Pertama-tama dilakukan uji awal, lalu dikenakan perlakuan untuk jangka waktu tertentu. Kemudian dilakukan uji akhir. Rancangan penelitian dapat digambarkan sebagai berikut:

\footnotetext{
7 Suryabrata, Sumadi.(2003). Metodologi Penelitian. Jakarta : PT Raja Grafindo

${ }^{8}$ Fraenkel, Jack R., (2014). How to design and evaluate research in education 7th. McGraw Hill Companies, Inc: New York.
} 
Tabel 1.1. Rancangan Penelitian ${ }^{9}$

\begin{tabular}{ccc}
\hline Pre test & Perlakuan & Post test \\
\hline $\mathrm{O}_{1}$ & $\mathrm{X}$ & $\mathrm{O}_{2}$ \\
\hline
\end{tabular}

Keterangan tabel:

$\mathrm{O}_{1}=$ uji awal (pretest), untuk mengetahui penguasaan awal siswa terhadap pengetahuan tentang materi sebelum diberikan perlakuan.

$\mathrm{X}=$ Perlakuan, yaitu pelaksanaan pembelajaran dengan menggunakan Model $P B L$ yang dikembangkan untuk jangka waktu tertentu.

$\mathrm{O}_{2}=$ uji akhir (posttest), untuk mengetahui penguasaan siswa terhadap pengetahuan tentang materi.

Sesuai dengan jenis data yang ingin diperoleh dalam penelitian ini, maka instrumen penelitian yang dikembangkan dan digunakan adalah sebagai berikut:

\section{Efektivitas Penerapan Perangkat Pembelajaran}

a. Lembar Angket Respon mahasiswa

Lembar angket respon siswa ini digunakan untuk memperoleh data mengenai pendapat/ komentar dari siswa tentang perangkat pembelajaran yang dikembangkan oleh peneliti. Minat adalah kecendrungan hati yang tinggi terhadap sesuatu atau keinginan yang tinggi terhadap sesuatu. Motivasi adalah dorongan yang timbul dalam diri seseorang secara sadar atau tidak sadar untuk melakukan suatu tindakan dengan tujuan tertentu.

b. Lembar pengamatan Aktivitas Mahasiswa

Lembar pengamatan Aktivitas ini digunakan untuk mengetahui kemampuan dan aktivitas mahasiswa dalam proses belajar mengajar serta mengamati penguasaan materi tentang pengetahuan konsep mengenai materi ajar sebagai suatu produk. Dalam menyusun instrumen pengamatan yang baik perlu untuk diketahui nilai koefisien reliabilitas.

Teknik pengumpulan data yang dilakukan menggunakan teknik sebagai berikut:

a. Observasi/Pengamatan

Observasi/pengamatan dilakukan untuk mengumpulkan data penelitian tentang aktivitas mahasiswa dan keterlaksanaan RPP saat kegiatan pembelajaran berlangsung.

9 Putra, M. I. S., Widodo, W. and Jatmiko, B. (2016). The development of guided inquiry science learning materials to improve science literacy skill of prospective mi teacher. Jurnal Pendidikan IPA Indonesia, JPII 5 (1) (2016) 83-93. 
b. Pemberian Tes

Pemberian tes digunakan untuk memperoleh data tentang hasil belajar mahasiswa dan ketuntasan tujuan pembelajaran, ketuntasan individu, klasikal, dan sensivitas butir soal.

c. Pemberian Angket

Pemberian angket dilakukan setelah proses belajar mengajar satu pokok bahasan berakhir. Angket digunakan untuk mengumpulkan informasi data tentang minat dan motivasi mahasiswa terhadap kegiatan pembelajaran menggunakan $\mathrm{PBL}$.

Tujuan analisis data dalam penelitian ini adalah untuk menjawab pertanyaanpertanyaan penelitian yang selanjutnya merumuskan simpulan. Berikut ini data-data penelitian yang akan dianalisis:

1. Analisis Efektivitas Penerapan Perangkat Pembelajaran

a. Analisis Data Respon mahasiswa

Data angket diperoleh dari dua macam data yang diberikan kepada mahasiswa, yaitu pertama: angket minat mahasiswa, kedua: angket motivasi mahasiswa terhadap proses pembelajaran. Teknik yang digunakan untuk menganalisis respon mahasiswa adalah statistik deskriptif.

b. Analisis Data Aktivitas mahasiswa

Data pengamatan diperoleh dari data yang diberikan oleh 2 pengamat selama proses pembelajaran. Teknik yang digunakan untuk menganalisis aktivitas mahasiswa adalah statistik deskriptif.

\section{HASIL PENELITIAN DAN PEMBAHASAN}

\section{A. Teori Model Problem Based Learning (PBL) untuk Meningkatkan Keterampilan Berpikir Kritis Mahasiswa}

Model Problem Based Learning (PBL) menggunakan masalah autentik dan bermakna yang ditemukan siswa sebagai titik awal untuk mengakuisisi pengetahuan baru. ${ }^{10}$ Ciri-ciri model PBL, yaitu mengorientasikan siswa kepada masalah autentik, berfokus pada keterkaitan antar disiplin, penyelidikan autentik, menghasilkan produk

10 Imafuku, R., Kataoka, R., Mayahara, M., Suzuki, H., \& Saiki, T. (2014). Students' experiences in interdisciplinary problem-based learning: A discourse analysis of group interaction. Interdisciplinary Journal of Problem-based Learning. Vol. 8 No. 2, pp. 1-19.

Stalker, S. L., Cullen, T., \& Kloesel, K. (2014). Using PBM to prepare educators and emergency managers to plan for severe weather. Interdisciplinary Journal of Problem-Based Learning. Vol. 9 No. 2, pp. 1-9.

Temel, S. (2014) The effects of problems based learning on pre service teachers's critical thinking dispotitions and perceptions of problems solving ability South African Journal of Education. Vol. 34, No. 1, pp. 1-20. 
atau karya dan memamerkannya, dan kolaborasi ${ }^{11}$. Sintaks dari model PBL pada Tabel 2.5 di bawah ini.

Tabel 2.5 Sintaks Model Problem Based Learning $(P B L)^{12}$

\begin{tabular}{|c|l|}
\hline FASE & \multicolumn{1}{c|}{ PERILAKU GURU } \\
\hline $\begin{array}{c}\text { Mengarahkan siswa ke } \\
\text { masalah. }\end{array}$ & $\begin{array}{l}\text { Guru meninjau ulang tujuan pembelajaran, menjabarkan } \\
\text { persyaratan logistik yang penting dan memotivasi siswa } \\
\text { untuk terlibat dalam kegiatan pemecahan masalah. }\end{array}$ \\
\hline $\begin{array}{c}\text { Mengorganisir siswa } \\
\text { untuk belajar. }\end{array}$ & $\begin{array}{l}\text { Guru membantu siswa untuk mendefinisikan dan } \\
\text { mengorganisasikan tugas-tugas belajar yang terkait } \\
\text { dengan permasalahan. }\end{array}$ \\
\hline $\begin{array}{c}\text { Membantu investigasi } \\
\text { mandiri dan kelompok. }\end{array}$ & $\begin{array}{l}\text { Guru mendorong siswa mendapat informasi yang tepat, } \\
\text { melaksanakan eksperimen dan memberi penjelasan dan } \\
\text { solusi. }\end{array}$ \\
\hline $\begin{array}{c}\text { Mengembangkan dan } \\
\text { mempresentasikan } \\
\text { artefak dan exhibit. }\end{array}$ & $\begin{array}{l}\text { Guru membantu siswa dalam merencanakan dan } \\
\text { menyiapkan artefak dan exhibit yang tepat seperti } \\
\text { laporan, rekaman video dan model-model. Guru } \\
\text { membantu siswa menyampaikan/mempresentasikan } \\
\text { kepada orang lain. }\end{array}$ \\
\hline $\begin{array}{c}\text { Menganalisis dan } \\
\text { mengevaluasi proses } \\
\text { pemecahan masalah. }\end{array}$ & $\begin{array}{l}\text { Guru membantu siswa untuk melakukan refleksi terhadap } \\
\text { investigasinya dan proses-proses yang mereka gunakan. }\end{array}$ \\
\hline
\end{tabular}

Model problem based learning masih memiliki beberapa hambatan yang harus diatasi apabila ingin penggunaannya lebih luas. Hambatan model PBL adalah kurang sesuai dengan cakupan informasi yang besar atau pengetahuan dasar dan beberapa guru tidak mendorong penggunaannya. ${ }^{13}$ Sockalingam \& Schmidt ${ }^{14}$ melakukan penelitian dengan sampel 34 menggunakan model PBL, hasil yang diperoleh menunjukkan kelemahan dari PBL, yaitu problem based learning akan efektif bila siswa sudah menguasai konsep-konsep dasar untuk memecahkan masalah. Ketika siswa belum mempunyai dan belum memahami konsep dasar maka siswa kesulitan dalam

${ }^{11}$ Batdi, V. (2014). The effects of problem based learning approach on students' attitude levels: A meta-analysis. Educational Research and Reviews. Vol. 9 No. 9, pp. 272-276.

12 Arends, Richard. L. (2012). Learning to Teach 9Th edition. MC-Graw Hill Companies, Inc: New York. York. P.244

${ }^{13}$ Arends, Richard. L. (2012). Learning to Teach 9Th edition. MC-Graw Hill Companies, Inc: New

14 Sockalingam, N. \& Schmidt, H. G. (2011). Characteristics of problems for problem-based learning: The students' perspective. Interdisciplinary Journal of Problem-Based Learning. Vol. 5 NO. 1, pp. 6-33. 
pemecahan masalah. Hasil penelitian Celik ${ }^{15}$ menemukan pada sampel 24 mahasiswa calon guru menggunakan PBL dapat meningkatkan hasil belajar mahasiswa calon guru, namun kemampuan menyelidiki dan kolaboratif siswa untuk memecahkan masalah masih rendah.

Hasil penelitian meta-analisis oleh Batdi16 terhadap hasil penelitian 2006 sampai 2013 menunjukkan bahwa pembelajaran PBL efektif dalam pembelajaran untuk melatihkan sikap siswa. Temuan lainnya adalah 1) lingkungan pembelajaran perlu diperhatikan lebih lanjut, sehingga siswa perlu memahami model PBL dan menguasai konsep terlebih dahulu, 2) model PBL belum menunjukkan mampu melatih keterampilan pemecahan masalah kolaboratif dan keterampilan berpikir kritis secara maksimal. Ketika keterampilan proses dan keterampilan berpikir kritis yang dimiliki peserta didik rendah ${ }^{17}$ dan keterampilan kolaboratif siswa dalam pemecahan masalah masih rendah ${ }^{18}$, maka akan menghambat proses pembelajaran di dalam kelas.

Pengembangan berpikir kritis dianggap sebagai salah satu tujuan yang paling penting dari ilmu pengetahuan pendidikan selama lebih dari satu abad ${ }^{19}$.Istilah-istilah seperti berpikir tingkat tinggi dan berpikir reflektif telah banyak digunakan secara bergantian dengan istilah berpikir kritis ${ }^{20}$. Banyak pendapat ahli dalam mendefinisikan berpikir kritis. Paul ${ }^{21}$ menyatakan berpikir kritis sebagai -"seni berpikir tentang berpikir secara disiplin intelektual." Menurut Paul, jenis pemikiran ini melibatkan tiga komponen penting, (1) analisis (analyzing), (2) menilai (assessing) dan (3) meningkatkan (improving).

${ }^{15}$ Celik, P., Onder, F., and Silay, I. (2011). The effects of problem-based learning on the students' success in physics course. Procedia-Social and Behavioral Sciences. Vol. 28 pp. 656-600.

16 Batdi, V. (2014). The effects of problem based learning approach on students' attitude levels: A meta-analysis. Educational Research and Reviews. Vol. 9 No. 9, pp. 272-276

17 Dogan, I \& Kunt, H. (2016). Determination of prospective preschool teachers' science process skills. Journal of European Education. 6 (1), 32-42.

18 OECD. (2013). PISA 2015 collaborative problem solving framework. OECD Publishing.

OECD. (2014). PISA 2012 Results: What students know and can do - student performance in mathematics, reading and science (Volume I, Revised edition, February 2014), PISA, OECD Publishing. Publishing.

OECD. (2015a). OECD Programme for International Student Assessment 2015. OECD

OECD. (2015b). The Experience of Middle-Income Countries Participating in PISA 2000-2015, PISA, World Bank, Washington, D.C. OECD Publishing.

19 Forawi, S.A. (2012). Perceptions on Critical Thinking Attributes of Science Education Standards. International Conference on Education and Management Innovation IPEDR vol.30 (2012) ( (2012) IACSIT Press, Singapore. 1-19.

${ }^{20}$ Geertsen, H. (2003). Rethinking thinking about higher-level thinking. Teaching Sociology. 31,

Wallace, A. Berry., \& D. Cave. (2009). Teaching Problem Solving and Thinking Skills through Science. Abington, Oxon: Routledge.

21 Paul, R.W. (1995). Critical thinking: How to prepare students for a rapidly changing world. Santa Rosa,CA: Foundation for Critical Thinking.

Paul, R.W. (2002). The International Center for the Assessment of Thinking: Critical thinking Essay Examination.Santa Rosa, CA: Foundation for Critical Thinking. 
Sebagai langkah awal proses menganalisis dan menilai, berpikir dibawa ke tingkat yang lebih kritis atau pemikiran yang dibuat lebih baik. Ini melibatkan gagasan menerapkan standar intelektual dan pengendalian diri pada orang-orang yang berpikir Definisi berpikir kritis sangat beragam dari yang sederhana sampai yang kompleks. Ennis $^{22}$ mendefinisikan berpikir kritis sebagai pemikiran reflektif dan reasonable berfokus pada memutuskan apa yang harus dilakukan. Paul menulis bahwa berpikir kritis menggunakan satu set standar pemikiran intelektual. Standar ini memandu proses berpikir dan membantu orang meningkatkan kemampuan untuk berpikir kritis. Berpikir tentang berpikir dalam rangka meningkatkan proses berpikir adalah jantung pemikiran kritis ${ }^{23}$. Pendapat Halpern ${ }^{24}$, bahwa berpikir kritis didefinisikan sebagai penggunaan keterampilan kognitif atau strategi yang meningkatkan kemungkinan hasil yang diinginkan.

Definisi lain meliputi: pembentukan kesimpulan logis ${ }^{25}$ mengembangkan penalaran hati-hati dan logis ${ }^{26}$, memutuskan tindakan apa yang harus diambil atau apa yang harus dipercaya melalui pemikiran reflektif yang wajar dan tujuan menentukan apakah akan menerima, menolak, atau menangguhkan penilaian ${ }^{27}$. Burden dan Byrd mengkategorikan berpikir kritis sebagai aktivitas berpikir tingkat tinggi yang memerlukan seperangkat keterampilan kognitif ${ }^{28}$. Pascarella \& Terezini menyatakan bahwa: "Berpikir kritis telah didefinisikan dan diukur dalam sejumlah cara, tetapi biasanya melibatkan kemampuan individu" untuk melakukan beberapa atau semua hal berikut: mengidentifikasi isu sentral dan asumsi dalam argumen, mengenali hubungan yang penting, membuat kesimpulan yang benar dari data, menyimpulkan kesimpulan dari informasi atau data yang diberikan, menginterpretasikan apakah kesimpulan dijamin didasarkan pada data yang disediakan, dan mengevaluasi bukti atau otoritas ${ }^{29}$

Pada dasarnya berpikir tidak dapat dilepaskan dan aktivitas manusia, karena berpikir merupakan ciri yang membedakan manusia dengan makhluk lainnya.

22 Ennis, R. H. (1991). Critical thinking: A streamlined conception. Teaching Philosophy, 14(1), 524. Thinking. Alexandria: ASCD.

${ }^{23}$ Paul, R.W. (1995). Critical thinking: How to prepare students for a rapidly changing world. Santa Rosa,CA: Foundation for Critical Thinking.

24 Halpern, D.F. (1996). Thought and knowledge: An introduction to critical thinking. Mahwah, NJ: Lawrence Erlbaum Associates.

25 Simon, H.A., \& Kaplan, C.A. (1989). Foundations of Cognitive Science. Cambridge, MA: MIT Press.

${ }^{26}$ Stahl, N.N., \& Stahl, R.J. (1991). We can agree a er all: Achieving a consensus for a critical thinking component of a gied program using the Delphi technique. Roeper Review, 14(2), 79-88.

${ }^{27}$ Moore, B.N., \& Parker, R. (1994). Critical thinking. Mountain View, CA: Mayfield. Bacon, Inc.

${ }^{28}$ Burden, P.R., \& Byrd, D.M. (1994). Methods for effective teaching. Boston, MA: Allyn and

29 Pascarella, E., \& Terenzini, P. (1991). How college affects students: Findings and insights from twenty years of research. San Francisco, CA: Jossey Bass 
Berpikir pada umumnya dedefinisikan sebagai proses mental yang dapat menghasilkan pengetahuan. Keterampilan berpikir dikelompokkan menjadi keterampilan berpikir dasar dan keterampilan berpikir tingkat tinggi. Menurut Costa $^{30}$ yang termasuk keterampilan berpikir dasar meliputi kualifikasi, klasifikasi, hubungan variabel, tranformasi, dan hubungan sebab akibat. Sedangkan keterampilan berpikir kompleks meliputi problem solving, pengambilan keputusan, berpikir kritis dan berpikir kreatif. Keterampilan berpikir kritis termasuk salah satu keterampilan berpikir tingkat tinggi. Keterampilan berpikir kritis. secara esensial merupakan keterampilan menyelesaikan masalah (problem solving). Menurut Ennis dalam berpikir kritis adalah kemampuan bernalar dan berpikir reflektif yang diarahkan untuk memutuskan hal-hal yang meyakinkan untuk dilakukan.31

Keterampilan berpikir kritis tersebut dirinci lebih lanjut menjadi indikatorindikator yang lebih spesifik untuk pembelajaran IPA oleh Liliasari32 yaitu : (1) mengidentifikasi/merumuskan pertanyaan; (2) menjawab pertanyaan mengapa, menjawab pertanyaan tetang alasan utama, menjawab pertanyaan tentang fakta; (3) mengidentifikasi kesimpulan, mengidentifikasi alasan yang dikemukakan, menemukan persamaan dan perbedaan, mengidentifikasi hal yang relevan, merangkum; (4) menyesuaikan dengan sumber, memberikan alasan, kebiasaan berhati-hati; (5) melaporkan berdasarkan pengamatan, melaporkan generalisasi eksperimen, mempertegas pemikiran, mengkondisikan cara yang baik; (6) menginterpretasikan pertanyaan; (7) menggeneralisasi, meneliti; (8) menerapkan prinsip yang dapat diterima, mempertimbangkan alternatif; (9) menentukan strategi terdefinisi, menentukan definisi materi subyek; (10) mengidentifikasi asumsi dari alasan yang tidak dikemukakan, mengkonstruksi pertanyaan; 11) merumuskan masalah, memilih kriteria untuk mempertimbangkan penyelesaian, merumuskan alternatifpenyelesaian, menentukan hal yang dilakukan secara tentatif, mempertimbangkan situasi lalu memutuskan; (12) menggunakan strategi logis.

Keterampilan berpikir kritis perlu dikembangkan dalam diri mahasiswa karena melalui keterampilan berpikir kritis mahasiswa dapat lebih mudah memahami konsep, peka akan masalah yang terjadi sehingga dapat memahami dan menyelesaikan

${ }^{30}$ Costa, A.L., (1985.) Developing Minds: A Resource Book for Teaching

${ }^{31}$ Putra, M. I. S., Widodo, W. and Jatmiko, B. (2016). The development of guided inquiry science learning materials to improve science literacy skill of prospective mi teacher. Jurnal Pendidikan IPA Indonesia, JPII 5 (1) (2016) 83-93.

32 Liliasari, dkk 1997. Pengembangan Model Pembelajaran Materi Subyek untuk Meningkatkan Keterampilan Berpikir Konseptual Tingkat Tinggi Mahasiswa Calon Guru IPA, Laporan Penelitian, Bandung: FPMIPA IKIP Bandung. 
masalah dan mampu mengaplikasikan konsep-konsep dalam situasi yang berbeda. Berpikir secara umum didefinisikan sebagai suatu proses kognitif, suatu aktivitas mental untuk memperoleh pengetahuan ${ }^{33}$ berpikir ternyata mampu mempersiapkan peserta didik berpikir pada berbagai disiplin ilmu serta dapat dipakai untuk pemenuhan kebutuhan intelektual dan pengembangan potensi pesera didik.

Proses berpikir dapat dikelompokkan dalam berpikir dasar dan berpikir komplek. Berpikir dasar merupakan gambaran dari proses berpikir rasional yang mengandung sejumlah langkah dari sederhana menuju yang komplek. Aktivitas berpikir rasional meliputi menghafal, membayangkan, mengelompokkan, menggeneralisasi, membandingkan, mengevaluasi, menganalisis, mensintesis, mendeduksi dan menyimpulkan ${ }^{34}$. Proses berpikir komplek yang disebut proses berpikir tingkat tinggi antara lain pemecahan masalah, pengambilan keputusan, berpikir kritis, dan berpikir kreatif ${ }^{35}$

Pembentukan konsep adalah proses berpikir membentuk kategori-kategori baru, sedangkan dalam pemahaman konsep, kategori-kategori tersebut sudah ada sebelumnya dan mahasiswa berupaya menentukan identitas dan definisi konsep. Seluruh proses ini hanya dapat diamati melalui tindakan yang didemonstrasikan oleh mahasiswa seperti, menyusun daftar contoh, mengelompokkan, atau memberi nama. Pembentukan konsep menggunakan proses berpikir induktif, sedangkan pemahaman konsep menggunakan proses berpikir deduktif.36

Bahwa hasil penelitian Jean Piaget, Jerome bruner, David Ausubel, dan Howard Gardner dan lain-lainnya menunjukkan bagaimana berpikir konseptual berkembang pada mahasiswa dan bagaimana pendekatan tertentu terhadap pembelajaran konsep mempengaruhi proses belajar mahasiswa dan hasil belajar mahasiswa. Pada seksi berikut ini kita akan mendiskusikan hubungan antara konsep dan berpikir tingkat tinggi, hakikat konsep, dan beberapa pengetahuan yang telah kita miliki tentang bagaimana cara terbaik mengajarkan konsep kepada mahasiswa.37

33 Liliasari. 1996. Beberapa pola berpikir dalam pembentukan pengetahuan kimia oleh siswa SMA. Disertasi. PPS IKIP Bandung.

34 Putra, MIS., Widodo, W, Jatmiko B. Mundilarto, M. (2018). The Development Of Science Cps (Collaborative Problem Solving) Learning Model To Improve Future Islamic Elementary School Teachers' Collaborative Problem-Solving Skills And Science Literacy. Unnes Science Education Journal 7 (1) 35-49

35 Presseisen, B.Z. 1985. "Thinking Skill: Meanings and Models". Dalam Costa, A.L. (ed). Developing Minds: A Resource Book For Teching Thinking. Alexandria: ASCD

36 Putra, MIS. (2016). Implementasi Pembelajaran IPA Model Inkuiri Terbimbing Untuk Meningkatkan Keterampilan Literasi Sains Calon Guru MI. Dirasat: Jurnal Manajemen dan Pendidikan Islam 1 (2), 263-284

37 Sulardi, Nur, M., Widodo, W. (2015). Pengembangan perangkat pembelajaran fisika model problem based learning (PBL) untuk melatih keterampilan berpikir kritis siswa. (Tesis Magister Pendidikan Tidak dipublikasikan). Pasca Sarjana UNESA. 
Pembelajaran PPKn dengan menggunakan model PBL lebih dari sekedar penyederhanaan pengklasifikasian objek dan membentuk kategori serta meningkatkan keterampilan berpikir kritis mahasiswa. Pembelajaran PPKn dengan menggunakan model PBL akan memperoleh konsep baru yang dapat diterapkan pada kehidupan sehari-hari. Pembelajaran PPKn dengan menggunakan model PBL meliputi proses mengkonstruksi pengetahuan dan mengorganisasi informasi ke dalam struktur kognitif yang komprehensif dan kompleks sehingga mampu mempertahankan respon mahasiswa selama pembelajaran.

\section{B. Hasil dan Pembahasan Penelitian}

Aktivitas mahasiswa dalam Proses Belajar Mengajar diamati dengan menggunakan teknik percentage of agreement dan pengamatan dilakukan oleh 2 orang pengamat. Rekapitulasi hasil perhitungan keterlaksanaan Aktivitas mahasiswa pada kegiatan belajar mengajar RPP 1 dan RPP 2 pada ujicoba dapat dilihat pada Tabel 1.2.

Tabel 1.2 Persentase dan Reliabilitas Instrumen Aktivitas Mahasiswa Selama KBM

\begin{tabular}{|c|c|c|c|c|}
\hline \multirow[t]{2}{*}{ No } & \multirow[t]{2}{*}{ Aspek yang diamati } & \multicolumn{3}{|c|}{$\begin{array}{l}\text { Persentase Aktivitas } \\
\text { Mahasiswa (\%) }\end{array}$} \\
\hline & & RPP I & RPP II & $\begin{array}{l}\text { Rata- } \\
\text { rata }\end{array}$ \\
\hline 1 & $\begin{array}{l}\text { Mengemukakan pendapat/ide- } \\
\text { ide }\end{array}$ & 15.9 & 16.0 & 15.9 \\
\hline 2 & $\begin{array}{l}\text { Memperhatikan } \\
\text { pendemonstrasian oleh dosen }\end{array}$ & 10.0 & 9.3 & 9.6 \\
\hline 3 & $\begin{array}{l}\text { Mengerjakan latihan yang } \\
\text { diberikan }\end{array}$ & 11.4 & 11.9 & 11.6 \\
\hline 4 & $\begin{array}{l}\text { Berdiskusi dengan pasangan } \\
\text { kelompok dalam mengerjakan } \\
\text { latihan }\end{array}$ & 10.4 & 10.5 & 10.4 \\
\hline 5 & $\begin{array}{lr}\text { Memperhatikan } & \text { kelompok } \\
\text { melakukan } & \text { pemodelan } \\
\text { pembelajaran PBL } & \\
\end{array}$ & 13.9 & 10.6 & 12.3 \\
\hline 6 & $\begin{array}{llr}\text { Menanggapi } & \text { pertanyaan yang } \\
\text { diberikan } & \text { oleh } & \text { kelompok } \\
\text { lain/dosen } & & \\
\end{array}$ & 11.3 & 11.5 & 11.4 \\
\hline 7 & $\begin{array}{l}\text { Berdiskusi antara mahasiswa } \\
\text { dan dosen }\end{array}$ & 13.1 & 20.4 & 16.8 \\
\hline 8 & $\begin{array}{l}\text { Menyimpulkan hasil kerja atau } \\
\text { materi pembelajaran }\end{array}$ & 11.8 & 9.1 & 10.4 \\
\hline 9 & $\begin{array}{l}\text { Perilaku yang tidak relevan: } \\
\text { Percakapan yang tidak relevan, } \\
\text { Mengerjakan sesuatu yang tidak } \\
\text { relevan, } \\
\text { Mengganggu teman, }\end{array}$ & 2.4 & 0.8 & 1.6 \\
\hline
\end{tabular}




\begin{tabular}{|l|l|c|c|c|}
\hline No & Aspek yang diamati & \multicolumn{3}{|c|}{$\begin{array}{c}\text { Persentase Aktivitas } \\
\text { Mahasiswa (\%) }\end{array}$} \\
\cline { 3 - 5 } & RPP I & RPP II & $\begin{array}{c}\text { Rata- } \\
\text { rata }\end{array}$ \\
\hline \multicolumn{2}{l}{$\begin{array}{l}\text { Melamun, dan } \\
\text { Mencari perhatian. }\end{array}$} & & & \\
\hline Jumlah & 100 & 100 & 100 \\
\hline Reliabilitas (\%) & 99.9 & 98.5 & 99.2 \\
\hline
\end{tabular}

Bahwa persentase rata-rata aktivitas mahasiswa untuk masing-masing aktivitas mahasiswa meliputi: mengemukakan pendapat, memperhatikan pendemonstrasian oleh dosen, mengerjakan latihan yang diberikan, berdiskusi dengan pasangan dalam mengerjakan latihan, memperhatikan kelompok melakukan pemodelan dalam pembelajaran $P B L$, menanggapi pertanyaan yang diberikan oleh kelompok lain/dosen, berdiskusi antara mahasiswa dan dosen, menyimpulkan hasil kerja atau materi pembelajaran, perilaku yang tidak relevan: (a) percakapan yang tidak relevan, (b) mengerjakan sesuatu yang tidak relevan, (c) mengganggu teman, (d) melamun, dan (e) mencari perhatian berturut-urut adalah 15,9 \%, 9,6\%, 11.6\%, 10,4\%, $12,3 \%, 11,4 \%, 16,8 \%, 10,4 \%, 1,6 \%$. Persentase aktivitas terbesar pada ujicoba ini adalah Berdiskusi antara mahasiswa dan dosen yaitu 16,8\%, hal ini disebabkan karena hasil belajar menggunakan perangkat model $P B L$ salah satunya adalah keterampilan berkomunikasi, sehingga mengemukakan pendapat memiliki persentase yang paling besar dibandingkan dengan aspek yang lain.

Untuk aspek Mengemukakan pendapat/ide-ide juga memiliki nilai persentase sebesar 15,9\%, hal ini disebabkan mahasiswa menyukai sesuatu yang bersifat baru, karena dalam pembelajaran model PBL yang diberikan terdapat hal-hal yang baru diketahui oleh mahasiswa. Persentase aktivitas terkecil adalah perilaku yang tidak relevan sebesar 1,6\%. Lebih jelasnya persentase aktivitas mahasiswa dalam pembelajaran dapat dilihat pada Gambar 1.1 di bawah ini: 


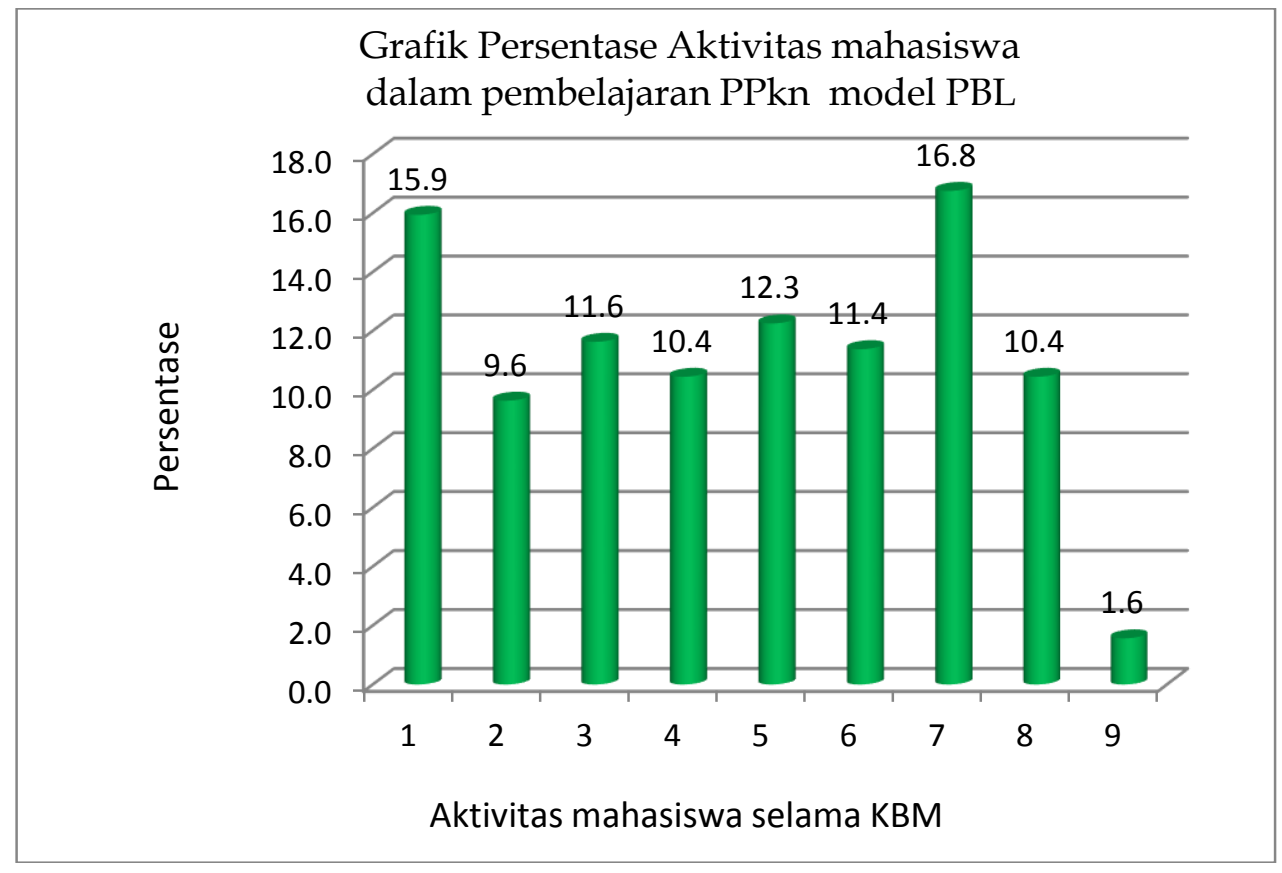

Gambar 1.1. Grafik Persentase Aktivitas Mahasiswa

Berdasarkan Data Grafik Persentase Aktivitas Mahasiswa pembelajaran PPKn dengan Model PBL bahwa Keterampilan berpikir kritis yang diharapkan muncul dari mahasiswa selama dan setelah pembelajaran adalah (1) menghasilkan ide/gagasan atau solusi baru (originalitas), (2) memberikan tanggapan secara rinci pada persoalan yang diberikan selama proses kegiatan belajar mengajar (elaborasi). Data di atas menunjukkan bahwa reliabilitas instrumen pengamatan aktivitas mahasiswa untuk masing-masing RPP rata-rata melebihi $75 \%$.

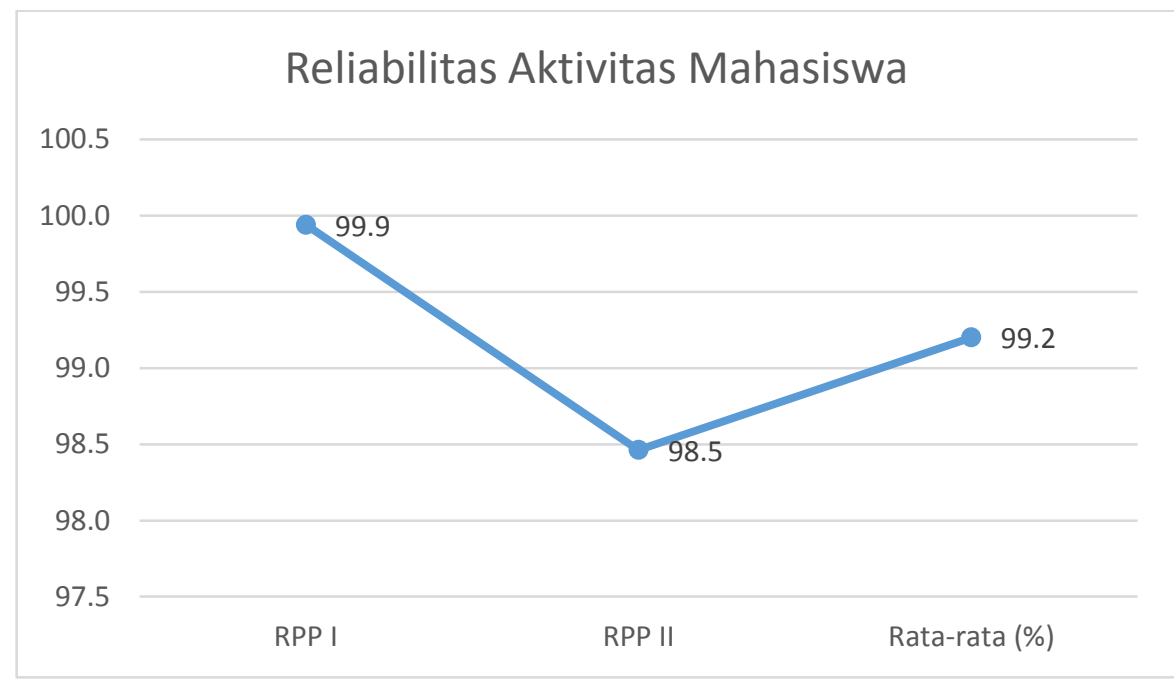

Gambar 1.2. Grafik Persentase Reliabilitas Aktivitas Mahasiswa 
Instrumen pengamatan terhadap aktivitas mahasiswa dalam KBM dikatakan reliabel apabila memiliki reliabilitas di atas $75 \%{ }^{38}$ Data respon mahasiswa terhadap pembelajaran menggunakan Pembelajaran $P B L$ yang diperoleh dikategorikan dalam respon terhadap pembelajaran dan motivasi terhadap pembelajaran. Respon adalah kecendrungan hati yang tinggi terhadap sesuatu atau keinginan yang tinggi terhadap sesuatu.

Data tentang respon mahasiswa terhadap pembelajaran dikategorikan dalam 4 komponen yang meliputi attention yaitu perhatian mahasiswa terhadap pembelajaran, relevance yaitu keterkaitan materi yang dipelajari dengan kebutuhan mahasiswa, convidence yaitu percaya diri mahasiswa selama mengikuti pembelajaran dan satisfaction yaitu kepuasan mahasiswa dalam mengikuti pembelajaran. Rekapitulasi data tentang respon mahasiswa terhadap pembelajaran dapat dilihat pada Tabel 1.3.

Tabel 1.3 Respon Mahasiswa Terhadap Pembelajaran Menggunakan Model PBL

\begin{tabular}{|l|l|c|l|}
\hline No & Komponen & $\begin{array}{l}\text { Respon } \\
\text { Ujicoba }\end{array}$ \\
\cline { 3 - 4 } & & Skor rata-rata & Kriteria \\
\hline $\mathbf{1}$ & Attention (perhatian) & 4.23 & Baik \\
\hline $\mathbf{2}$ & Relevance (keterkaitan) & 3.67 & Baik \\
\hline $\mathbf{3}$ & $\begin{array}{l}\text { Convidence (percaya } \\
\text { diri) }\end{array}$ & 3.86 & Baik \\
\hline $\mathbf{4}$ & Satisfaction (kepuasan) & 3.78 & Baik \\
\hline
\end{tabular}

Keterangan : kategori nilai skor rata-rata gabungan dari kriteria pernyataan positif dan negatif ${ }^{39}$
$1.00-1.49=$ tidak baik
$1.50-2.49=$ kurang baik
$3.50-4.49=$ baik
$2.50-3.49=$ cukup baik
$4.50-5.00=$ sangat baik

38 Putra, M.I.S. (2015) Pembelajaran IPA dengan Model Pembelajaran SSCS ( Search, Solve, Create, and Share) untuk meningkatkan hasil belajar mahasiswa PGMI Unipdu Jombang. Jurnal Pendidikan Sekolah Dasar. Vol. 7 No. 5 Mei 2015. ISSN: 1411-3805

39 Putra, M. I. S., Widodo, W. and Jatmiko, B. (2016). The development of guided inquiry science learning materials to improve science literacy skill of prospective mi teacher. Jurnal Pendidikan IPA Indonesia, JPII 5 (1) (2016) 83-93. 


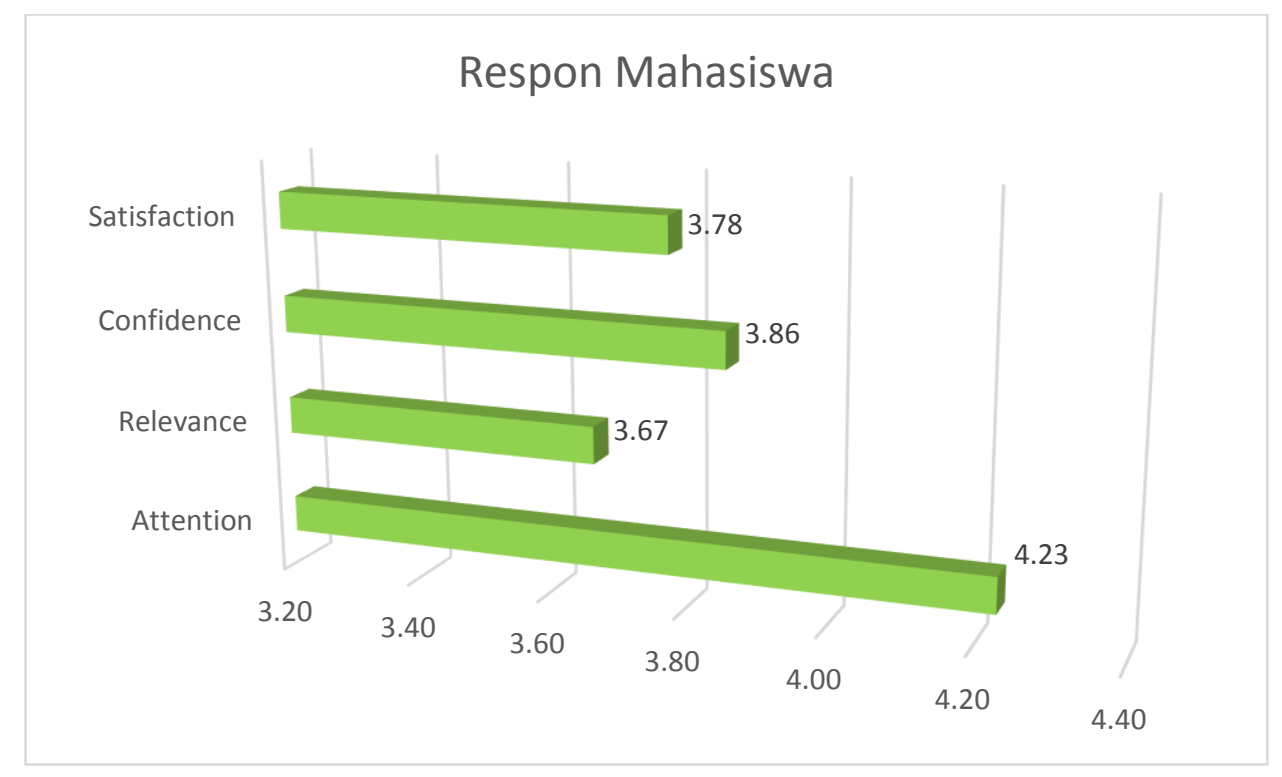

Gambar 1.3. Grafik respon mahasiswa terhadap pembelajaran menggunakan $P B L$

Gambar 1.3. menunjukkan skor rata-rata respon mahasiswa yang meliputi komponen: Perhatian mahasiswa terhadap pembelajaran masing-masing 4.23 dengan kategori baik, keterkaitan materi yang dipelajari dengan kebutuhan mahasiswa mempunyai masing-masing 3,67 dengan kategori baik, percaya diri mahasiswa selama mengikuti pembelajaran 3.86 dengan kategori baik, dan kepuasan mahasiswa dalam mengikuti pembelajaran 3,78 dengan kategori baik.

\section{PENUTUP}

Berdasarkan temuan pada penelitian tentang pembelajaran PPKN menggunakan $P B L$ dapat disimpulkan bahwa: ujicoba pembelajaran PPKN menggunakan $P B L$ yang dikembangkan dapat dikatakan efektif menunjang hasil belajar dan kegiatan belajar mengajar mahasiswa. Ujicoba pembelajaran efektif menunjang kegiatan belajar mengajar yang didasarkan pada rata-rata pengelolaan pembelajaran berkategori baik. keseluruhan sintaks Model Pembelajaran PBL terlaksana $100 \%$. Aktivitas mahasiswa selama kegiatan belajar mengajar menunjukkan bahwa mahasiswa belajar aktif dengan Presentase aktivitas terbesar pada ujicoba ini adalah mengemukakan pendapat yaitu $15,8 \%$.

Respon mahasiswa terhadap Model Pembelajaran PBL adalah kategori baik dan positif. Dengan rincian Perhatian (Attention) mahasiswa terhadap pembelajaran masing-masing 4.23 dengan kategori baik, keterkaitan (Relevance) materi yang dipelajari dengan kebutuhan mahasiswa mempunyai masing-masing 3,67 dengan 
kategori baik, percaya diri (Confidence)mahasiswa selama mengikuti pembelajaran 3,86 dengan kategori baik, dan kepuasan (Satisfaction) mahasiswa dalam mengikuti pembelajaran 3,78 dengan kategori baik

\section{DAFTAR PUSTAKA}

Ageorges, P., Bacila, A., Poutot, G., Blandin, B. (2014). Some lessons from a 3year experiment of problem based learning in physics in a French school of engineering. American Journal of Educational Research. Vol. 2 No. 8, pp. 564567.

Arends, Richard. L. (2012). Learning to Teach $9^{\text {Th }}$ edition. MC-Graw Hill Companies, Inc: New York.

Batdi, V. (2014). The effects of problem based learning approach on students' attitude levels: A meta-analysis. Educational Research and Reviews. Vol. 9 No. 9, pp. 272-276.

Burden, P.R., \& Byrd, D.M. (1994). Methods for effective teaching. Boston, MA: Allyn and Bacon, Inc.

Celik, P., Onder, F., and Silay, I. (2011). The effects of problem-based learning on the students' success in physics course. Procedia-Social and Behavioral Sciences. Vol. 28 pp. 656-600.

Costa, A.L., (1985.) Developing Minds: A Resource Book for Teaching

Dogan, I \& Kunt, H. (2016). Determination of prospective preschool teachers' science process skills. Journal of European Education. 6 (1), 32-42.

Ennis, R. H. (1985). “Goals For A Critical Thinking Curriculum”. Dalam Costa, A.L. (ed). Developing minds: A Resource Book For Teaching Thinking. Alexandria: ASCD.

Ennis, R. H. (1991). Critical thinking: A streamlined conception. Teaching Philosophy, 14(1), 5-24. Thinking. Alexandria: ASCD.

Forawi, S.A. (2012). Perceptions on Critical Thinking Attributes of Science Education Standards. International Conference on Education and Management Innovation IPEDR vol.30 (2012) @ (2012) IACSIT Press, Singapore.

Fraenkel, Jack R., (2014). How to design and evaluate research in education $7^{\text {th }}$. McGraw Hill Companies, Inc: New York.

Geertsen, H. (2003). Rethinking thinking about higher-level thinking. Teaching Sociology. 31, 1-19.

Halpern, D.F. (1996). Thought and knowledge: An introduction to critical thinking. Mahwah, NJ: Lawrence Erlbaum Associates.

Imafuku, R., Kataoka, R., Mayahara, M., Suzuki, H., \& Saiki, T. (2014). Students' experiences in interdisciplinary problem-based learning: A discourse analysis of group interaction. Interdisciplinary Journal of Problem-based Learning. Vol. 8 No. 2, pp. 1-19.

Klegeris, A., Bahniwal, M., Hurren, H. (2013) Improvement in generic problemsolving abilities of students by use of tutor-less problem-based learning in a large classroom setting. Life Sciences Education. Vol. 12, pp. 73-79.

Liliasari, dkk 1997. Pengembangan Model Pembelajaran Materi Subyek untuk Meningkatkan Keterampilan Berpikir Konseptual Tingkat Tinggi Mahasiswa Calon Guru IPA, Laporan Penelitian, Bandung: FPMIPA IKIP Bandung.

Liliasari. 1996. Beberapa pola berpikir dalam pembentukan pengetahuan kimia oleh siswa SMA. Disertasi. PPS IKIP Bandung. 
Moore, B.N., \& Parker, R. (1994). Critical thinking. Mountain View, CA: Mayfield.

Moreno, R. (2010). Educational psichology. New Mecico. John Wiley \& Sons, Inc.

OECD. (2013). PISA 2015 collaborative problem solving framework. OECD Publishing.

OECD. (2014). PISA 2012 Results: What students know and can do - student performance in mathematics, reading and science (Volume I, Revised edition, February 2014), PISA, OECD Publishing.

OECD. (2015a). OECD Programme for International Student Assessment 2015. OECD Publishing.

OECD. (2015b). The Experience of Middle-Income Countries Participating in PISA 2000-2015, PISA, World Bank, Washington, D.C. OECD Publishing.

Pascarella, E., \& Terenzini, P. (1991). How college affects students: Findings and insights from twenty years of research. San Francisco, CA: Jossey Bass

Paul, R.W. (1995). Critical thinking: How to prepare students for a rapidly changing world. Santa Rosa,CA: Foundation for Critical Thinking.

Paul, R.W. (2002). The International Center for the Assessment of Thinking: Critical thinking Essay Examination.Santa Rosa, CA: Foundation for Critical Thinking.

Prahani, B. K., Nur, M., Yuanita, L. (2016). Validitas Model Self Confidence Collaborative Problem Solving. Seminar Nasional Unesa. Surabaya, 23 Januari 2016.

Presseisen, B.Z. 1985. "Thinking Skill: Meanings and Models". Dalam Costa, A.L. (ed). Developing Minds: A Resource Book For Teching Thinking. Alexandria: ASCD

Putra, M.I.S. (2015) Pembelajaran IPA dengan Model Pembelajaran SSCS ( Search, Solve, Create, and Share) untuk meningkatkan hasil belajar mahasiswa PGMI Unipdu Jombang. Jurnal Pendidikan Sekolah Dasar. Vol. 7 No. 5 Mei 2015. ISSN: $1411-3805$

Putra, M. I. S., Widodo, W. and Jatmiko, B. (2016). The development of guided inquiry science learning materials to improve science literacy skill of prospective mi teacher. Jurnal Pendidikan IPA Indonesia, JPII 5 (1) (2016) 83-93.

Putra, MIS. (2016). Implementasi Pembelajaran IPA Model Inkuiri Terbimbing Untuk Meningkatkan Keterampilan Literasi Sains Calon Guru MI. Dirasat: Jurnal Manajemen dan Pendidikan Islam 1 (2), 263-284

Putra, MIS., Widodo, W, Jatmiko B. Mundilarto, M. (2018). The Development Of Science Cps (Collaborative Problem Solving) Learning Model To Improve Future Islamic Elementary School Teachers' Collaborative Problem-Solving Skills And Science Literacy. Unnes Science Education Journal 7 (1) 35-49

Rosa, O. F. (2015). Pengembangan modul pembelajaran IPA SMP pada materi tekanan berbasis keterampilan proses sains. Jurnal Pendidikan Fisika. Vol. 3 No. 1. 49-63.

Simon, H.A., \& Kaplan, C.A. (1989). Foundations of Cognitive Science. Cambridge, MA: MIT Press.

Skinner, V. J., Braunack-Mayer, A. , \& Winning, T. A. (2015). The purpose and value for students of PBL groups for learning. Interdisciplinary Journal of Problembased Learning, 9(1).

Sockalingam, N. \& Schmidt, H. G. (2011). Characteristics of problems for problembased learning: The students' perspective. Interdisciplinary Journal of Problem-Based Learning. Vol. 5 NO. 1, pp. 6-33.

Stahl, N.N., \& Stahl, R.J. (1991). We can agree a er all: Achieving a consensus for a critical thinking component of a gied program using the Delphi technique. Roeper Review, 14(2), 79-88.

Stalker, S. L., Cullen, T., \& Kloesel, K. (2014). Using PBM to prepare educators and emergency managers to plan for severe weather. Interdisciplinary Journal of Problem-Based Learning. Vol. 9 No. 2, pp. 1-9. 
Sulardi, Nur, M., Widodo, W. (2015). Pengembangan perangkat pembelajaran fisika model problem based learning (PBL) untuk melatih keterampilan berpikir kritis siswa. (Tesis Magister Pendidikan Tidak dipublikasikan). Pasca Sarjana UNESA.

Suryabrata, Sumadi.(2003). Metodologi Penelitian. Jakarta : PT Raja Grafindo

Temel, S. (2014) The effects of problems based learning on pre service teachers's critical thinking dispotitions and perceptions of problems solving ability South African Journal of Education. Vol. 34, No. 1, pp. 1-20.

Wallace, A. Berry., \& D. Cave. (2009). Teaching Problem Solving and Thinking Skills through Science. Abington, Oxon: Routledge. 